\title{
ROLE OF PARENTING STYLES IN ACADEMIC PERFORMANCE OF COLLEGE STUDENTS
}

\author{
SaminaYasmin $^{*}$ \\ Almas Kiani $^{* *}$
}

\begin{abstract}
The current study was designed to identify parenting styles based on parents' perception and to examine the relationship of parenting styles with students' academic performance. Baumrind's (1971) theoretical model of parenting styles was used. It is comprised of authoritative, authoritarian and permissive parenting styles. The Parental Authority Questionnaire (Buri, 1991) was used and modified in order to assess the three parenting styles based on parents' perception. After consultation with experts, Researcher developed the Academic Performance Questionnaire, which was used to assess the students' performance with regard to their educational motivation, communication skills, learning skills, creativity, positive attitude and study skills in this correlational study. Both instruments were developed on five point Likert scale. The target population of the study comprised of students of higher secondary level along with their parents studying at 17 Islamabad Model Colleges of both boys and girls. The sample was drawn from 10 Islamabad Model Colleges. The total number of respondents comprising the sample was 350 students 17-20 years old. Stratified random sampling was used to represent both genders equally. The correlation between parenting styles and academic performance was computed through Pearson's correlation coefficient ( $r$ ). The results of study showed that authoritative parenting style of mother and father had a positive relationship with academic performance. While the authoritarian and permissive parenting style of mother and father were negatively correlated with academic performance. Overall, the authoritative style of parenting proved to be
\end{abstract}

* M. Phil Scholar, Division of Continuing Education, Arid Agriculture University (AAU), Rawalpindi, Pakistan

${ }^{* *}$ Assistant Professor, Division of Continuing Education, AAU, Rawalpindi, Pakistan 
appositive style and authoritarian and permissive styles proved to be negative styles of parenting in the cultural context of Islamabad.

Keywords: Parenting styles, Academic Performance, Motivation, Skills.

\section{Introduction}

Parents play pivotal role in the development of their children. They should utilize positive parenting techniques for training their children. Future generation is the asset of a nation. They need to experience a healthy and positive psycho-social development, which enables them to succeed in every field of life including education. Baumrind (1971) developed theoretical model of parenting. This model is comprised of three parenting styles named as; authoritative, authoritarian and permissive. These styles are based on two dimensions known as demandingness and responsiveness. Authoritative parenting maintains a balance of both demandingness and responsiveness. Responsiveness refers to the supportiveness and warmth, and demandingness refers to behavioral control (Terry, 2004). In contrast, authoritarian parents are unresponsive. They stick to only one dimension that is demandingness. The permissive parents are responsive but are undemanding. The present study attempted to investigate the relationship of three basic parenting styles authoritative, authoritarian and permissive presented by Baumrind (1971) with their children's academic performance.

This study aimed at finding the relationship between parenting styles and academic performance of students. The study comprised of these three objectives: to find out the relationship of authoritative parenting style and academic performance of students, to find out the relationship of authoritarian parenting styles and academic performance of students, to find out the relationship of permissive parenting style and academic performance of students. The objectives of the study were tested through these six directional hypotheses: there is a significant positive relationship between authoritative maternal parenting styles and children's academic performance, there is a significant negative relationship between authoritarian maternal parenting styles and children's academic performance, there is a significant negative relationship between permissive maternal parenting styles and children's academic performance, there is a significant positive relationship between authoritative paternal parenting 
styles and children's academic performance, there is a significant negative relationship between authoritarian paternal parenting styles and children's academic performance, there is a significant negative relationship between permissive paternal parenting style and children's academic performance.

\section{Literature Review}

In authoritative style parents demand and expect maturity from their children. Parents take disciplinary and supervisory measures for making their children mature ones (Baumrind, 1991). Parents intentional' behavior, that can create qualities of individuality, self-regulation and self-assertion in their children, is considered as responsiveness. The extent of parents' sensitiveness and supportiveness towards their children exhibit parental responsiveness (Baumrind, 1991; Lazar, Gutmann \& Abas, 2009).These parents monitor and regulate children's attitude, while at the same time, provide support and warmth (Baumrind, 1971). They pay attention to children's compliance and set standard rules while providing autonomy to children. They acknowledge their kids' perspective, provide them freedom in choice making and empower their children's' opinion in family matter (Bersg, 2011; Zupancic, Podlesek, \& Kavcic, 2004). This style is considered perfect for all family units regardless of the ethnicity contrasts.

Authoritarian parents exhibit unfriendly attitude with their children and demand them to follow rules and decision without any argument. Authoritarian parents restrain children's self-expression and freedom desires, and use power-assertive techniques (physical force, love withdrawal, commands, threats) to achieve what they want from their children (Zupancic et al., 2004). These parents oblige compliance and set elevated requirements. They focus on success aspects and love is conditional with achievement. They are less nurturing than the other two styles of parenting (Berg, 2011). Parental extreme demandingness or control can include strict regulations, imposition of decisions and parental beliefs, all of these parental characteristics show use of power in extreme form (Lazar et al., 2009).

Permissive parents follow a tolerant approach for the sake of children's socialization. These parents mostly ignore misconduct displayed by children. These parents does not maintain control over child's conduct, 
however they exhibit a tolerant and supportive attitude (Zupancic et al., 2004). Permissive parents allow their children to experience a high level of freedom and do not impose rules and regulation to restrain their practices, unless physical harm is expected (Rossman \& Rea, 2005). They demand little or almost nothing from their children and maintain a friendly interrelation (Berg, 2011).

Academic performance is the combination of various educational outcomes in students. Performance is indicated through various aspects, which differ from institution to institution. Indicators of performance can include motivation, study skills, communication skills, creativity, creative writing, grades, student's working skills, self-realization, selfreliance and attitude. Various strategies are needed to adopt for reaching educational goals. The selection of positive and negative strategies is dependent upon parenting style, which is responsible of training and rearing the child. Research reveals that the children belonging to authoritative parents practice adaptive achievement strategies which ensure low level of failure- expectation, task- irrelevant behavior, passivity and self-enhancing attributions, while children from neglectful families practice maladaptive strategies responsible for the lack of selfenhancing attributions, and high level of passivity and task- irrelevant behavior (Kaisa, Hakan \& jari-erik, 2000). A study found that the positive parenting produces a healthy and successful student (Hoghughi \& Long, 2004).A firm and positive sense of self and self - esteem can be enhanced through parenting. The student, who is well cared, would be emotionally strong, resilient and socially competent. These students have the capacity to explore new opportunities. Research shows the association of adolescents' achievement strategies with parenting styles in the family. Findings revealed a significant effect of parenting styles on academic performance (Kaisa et al., 2000). Baumrind, as cited in Mckay, 2006) showed that children of authoritative parents excel in personality aspects such as creativity, independence, persistence, self-control and other skills such as social skills, academic competence, leadership skills, social perspective taking (Mckay, 2006). A higher self-esteem and social competence was found in children reared by authoritative parents (Baumrind, as cited in Cramer, 2002). Self-reliance and respect for their parents was observed (Baumrind, 1991).

Authoritarian Parenting is mostly found to influence academic performance negatively. There are many evidences in the literature 
regarding the claim that authoritative parenting is related to lower grades (Kordi \& Baharudin, 2010; Alsheikh, Parameswaran \& Elhoweris, 2010). Research showed that authoritarian parenting is related to higher levels of school problems (Roche, Ensminger \& Cherlin, 2007) and low academic achievement (Attaway \& Bry, 2004). A research study showed a negative correlation between permissive parenting and academic grades in families where parents have no involvement in their children's education and has not taken an initiative for a give-and-take relationship with their children (Kordi \& Baharudin, 2010; Alsheikh et al., 2010).

\section{Methodology}

This section deals with tool development and strategies employed for collecting and analyzing data for the current study.

Research Design: The study was based on inferential statistics. It was a survey type of research that used Parental Authority Questionnaire (PAQ), which was actually developed by Buri (1991). This questionnaire aimed to identify a range of parenting styles presented by Baumrind (1991).The Academic Performance Questionnaire (APQ) was used to measure number of indicators (motivation, communication skills, learning skills, creativity, positive attitude and study skills). The both scales used in study were Likert type scales, ranging from strongly agree to strongly disagree. In this study, researcher aimed to point out both positive and negative relationship of parenting styles with academic performance of students. Finally, the collected data related to major study variables was analyzed, keeping in view both the demographic as well as cultural context of Islamabad Capital Territory.

Participants: The participants were students of higher secondary level studying at 10 Islamabad Model colleges. Parents of same students also participated in study. Stratified sampling technique was used to select the colleges and students along with their parents. Two strata of students along with their parents were formulated. A number of 350 students of 17 to 20 years of age participated in this study. Only those students were selected who have both parents alive. 
Table 1

Sampling Framework of Islamabad Model Colleges of Boys and Girls

\begin{tabular}{clc}
\hline S. \# & \multicolumn{1}{c}{ Name of Institution } & $\begin{array}{c}\text { Number of } \\
\text { sample } \\
\text { students }\end{array}$ \\
\hline 1. & Islamabad college for Boys, G-6/3 & 35 \\
2. & Islamabad Model College for Boys, F-8/4 & 35 \\
3. & Islamabad Model College for Boys, F-7/3 & 35 \\
4. & Islamabad Model College for Boys, G-10/4 & 35 \\
5. & Islamabad Model College for Boys, F-10/3 & 35 \\
6. & Islamabad College for Girls, F-6/2 & 35 \\
7. & Islamabad Model College for Girls, F-6/2 & 35 \\
8. & Islamabad Model College for Girls, F-7/4 & 35 \\
9. & Islamabad Model College for Girls, F-10/2 & 35 \\
10. & Islamabad Model College for Girls, F-8/1 & 35 \\
\hline Total & & 350 \\
\hline
\end{tabular}

Instruments: Parental Authority Questionnaire-PAQ (Buri 1991) was used for data collection. Basically, it was designed to know the children's views about their parents monitoring techniques. Researcher modified this scale further to utilize it for identifying parents' perceptions. It allows responses on five point Likert scale ranging from strongly agree to strongly disagree. There are two parts in PAQ, each part consists of 30 items. The part- 1 of the scale measures the attitude of mother towards her child. The Part-2 of the scale measures the attitude of father towards his child. Item numbers 4, 5, 8, 11, 15, 20, 22, 23, 27 and30 are designed for authoritative style and item numbers2, 3, 7, 9, 12, 16, 18, 25, 26 and 29 are designed for authoritarian style. For permissive style, the selected item numbers are 1, 6, 10, 13, 14, 17, 19, 21, 24 and 28.

Academic performance of the students was measured through Academic Performance Questionnaire, which was developed after discussing with a panel of experts. It was based on performance indicators and consisted of 38 items with: Academic Motivation (6 items), Communication skills (6 items), Learning skills (6 items), Creativity (6 items), Positive 
Attitude (8 items), Study skills (6 items). It was responded on five point Likert scale ranging from Strongly Agree to Strongly Disagree. There were 7 items, which were marked reversely; these include serial numbers 5, 9, 10, 20, 26, 29 and 31.

Reliability and Validity: Researcher consulted experts throughout the questionnaire translation and modification process. After validation, the reliability of final questionnaire was tested. Finally, the instrument was pilot tested to the parents of 60 students. The reliability coefficient was calculated for each subscale of parenting. The Alpha Reliability for subscales are: .777 for authoritative paternal style, .646 for authoritarian paternal style, .554 for permissive paternal style, .711 for authoritative maternal style, .661 for authoritarian maternal style and .531 for permissive maternal style. The values for all subscales were found satisfactory.

During the formation of Academic Performance Questionnaire, experts' suggestions were taken. After validation, the reliability of final questionnaire was tested. For this, the instrument was pilot tested to 60 students selected from two boys and girls colleges. The reliability coefficient was found to be .78 which is considered to be quite satisfactory.

Data Analysis: After collection of the data, the responses were quantified and the data was tabulated through the use of Statistical Packages for the Social Sciences (SPSS).

Pearson Product - Moment Correlation (r) was used to find the relationship of parenting styles with academic performance as a whole and also with all indicators of performance one by one.

\section{Results}

Correlation Analysis: Correlation analysis was performed to investigate six hypotheses, which indicated the negative and positive correlation with three parenting styles of mother and father. Firstly, the correlation was computed as a whole and then gender wise analysis was calculated. 
Table 2

Relationship of Maternal Parenting Styles and Academic Performance Scale $(n=350)$

\begin{tabular}{lccc}
\hline Scale & Authoritative & Authoritarian & Permissive \\
\hline Academic & & & \\
Performance & $.481^{* * *}$ & $-.323^{* * *}$ & $-.106 *$ \\
Motivation & $.278^{* * *}$ & $-.251^{* * *}$ & $-.210^{* * *}$ \\
Communication & $.422 * * *$ & $-.349 * * *$ & -.019 \\
Learning & $.455^{* * *}$ & $-.243^{* * *}$ & $-.163^{* *}$ \\
Creativity & $.548^{* * *}$ & $-.298^{* * *}$ & .002 \\
Positive Attitude & $.275^{* * *}$ & $-.287 * * *$ & -.069 \\
Study Skill & $.224 * * *$ & -.054 & -.026 \\
Marks & $.213^{* * *}$ & $-.204^{* * *}$ & -.037 \\
\hline
\end{tabular}

Table 2 shows that academic performance and its indicators have strong positive correlation with authoritative. It has strong negative correlation with authoritarian except on one indicator i.e., study skills. It is negatively correlated with permissive parenting of mother. However, the relationship is weak. The range of correlation co-efficient varies from .002 to .548 .

Table 3

Relationship of Paternal Parenting Styles and Academic Performance Scale $(n=350)$

\begin{tabular}{lccc}
\hline Scale & Authoritative & Authoritarian & Permissive \\
\hline Academic & $.359^{* * *}$ & $-.171^{* *}$ & $-.184^{* *}$ \\
Performance & $.243^{* * *}$ & -.100 & $-.263^{* * *}$ \\
Motivation & $.355^{* * *}$ & $-.277^{* * *}$ & -.058 \\
Communication & $.310^{* * *}$ & $-.133^{*}$ & $-.268^{* * *}$ \\
Learning & $.374^{* * *}$ & $-.162^{* *}$ & -.069 \\
Creativity & $.183^{* *}$ & $-.131^{*}$ & -.068 \\
Positive Attitude & $.189^{* * *}$ & .020 & $-.119^{*}$ \\
Study Skill & $.255^{* * *}$ & $-.148^{* *}$ & -.050 \\
Marks & & & \\
\hline
\end{tabular}


Table 3 shows that authoritative style has significant positive correlation with academic performance and its indicators. Authoritarian style has negative correlation with academic performance, however relationship is non-significant for motivation and study skills. There is a weak correlation between permissiveness and academic performance but the relationship is non-significant for communication skills, creativity and positive attitude. The range of correlation co-efficient varies from .020 to .374 .

\section{Correlation Analysis Strata Wise}

Table 4

Relationship of Maternal Parenting Styles and Academic Performance of female students $(n=175)$

\begin{tabular}{lccc}
\hline \multicolumn{1}{c}{ Scale } & Authoritative & Authoritarian & Permissive \\
\hline Academic & $.471^{* * *}$ & $-.447^{* * *}$ & -.098 \\
Performance & $.320^{* * *}$ & $-.354^{* * *}$ & $-.195^{*}$ \\
Motivation & $.413^{* * *}$ & $-.406^{* * *}$ & .008 \\
Communication & $.438^{* * *}$ & $-.402^{* * *}$ & -.104 \\
Learning & $.534^{* * *}$ & $-.377^{* * *}$ & -.047 \\
Creativity & $.284^{* * *}$ & $-.351^{* * *}$ & -.081 \\
Positive Attitude & $.216^{* *}$ & $-.206^{* *}$ & -.047 \\
Study Skill & $.204^{* *}$ & -.120 & .006 \\
Marks & & & \\
\hline
\end{tabular}

Table 4 shows that academic performance and its indicators have strong positive correlation with authoritative parenting. Authoritarian style has strong negative correlation with academic performance except marks, which have non-significant correlation. There is no relationship between permissiveness and academic performance except one indicator i.e. motivation which have weak relation. The range of correlation co-efficient varies from .008 to .534. 
Table 5

Relationship of Paternal Parenting Styles and Academic Performance of female students $(n=175)$

\begin{tabular}{lccc}
\hline Scale & Authoritative & Authoritarian & Permissive \\
\hline Academic & $.416^{* * *}$ & $-.230^{* *}$ & $-.159^{*}$ \\
Performance & $.288^{* * *}$ & -.127 & $-.235^{* *}$ \\
Motivation & $.376^{* * *}$ & $-.283^{* * *}$ & -.068 \\
Communication & $.371^{* * *}$ & $-.238^{* *}$ & $-.231^{* *}$ \\
Learning Skills & $.426^{* * *}$ & $-.205^{* *}$ & -.088 \\
Creativity & $.261^{* * *}$ & $-.158^{*}$ & -.052 \\
Positive Attitude & $.231^{* *}$ & -.053 & -.070 \\
Study Skill & $.384^{* * *}$ & -.147 & -.033 \\
Marks & & &
\end{tabular}

Table 5 shows that Authoritative style has a significant positive correlation with academic performance and its all indicators. The Authoritarian style has significant negative correlation with academic performance and its indicators except motivation and study skills, which have non-significant correlation. There is a weak negative correlation between permissive paternal style and academic performance. The permissive style is found correlated with only motivation and learning skills. All other indicators have non-significant correlation with permissiveness. The range of correlation co-efficient varies from .033 to .426.

Table 6

Relationship of Maternal Parenting Styles and Academic Performance of male students $(n=175)$

\begin{tabular}{llll}
\hline Scale & Authoritative & Authoritarian & Permissive \\
\hline Academic & & & \\
Performance & $.463^{* * *}$ & $-.225^{* *}$ & -.143 \\
Motivation & $.199^{* *}$ & $-.172^{*}$ & $-.250^{* *}$ \\
Communication & $.403^{* * *}$ & $-.319^{* * *}$ & -.070 \\
Learning & $.436^{* * *}$ & -.114 & $-.254^{* *}$ \\
Creativity & $.540^{* * *}$ & $-.248^{* *}$ & .025 \\
Positive Attitude & $.251^{* *}$ & $-.237^{* *}$ & -.071 \\
Study Skill & $.226^{* *}$ & .074 & -.015 \\
Marks & $.235^{* *}$ & $-.267^{* * *}$ & .067 \\
\hline
\end{tabular}


Table 6 shows that the Authoritative style has significant positive correlation with academic performance and its indicators. Authoritarian style has negative correlation with academic performance and its indicators except study skills and learning, which have non-significant correlation. The permissive style has negative non-significant correlation with academic performance. The range of correlation co-efficient varies from .015 to .540.

Table 7

Relationship of Paternal Parenting Styles and Academic Performance of male students $(n=175)$

\begin{tabular}{lcll}
\hline Scale & Authoritative & Authoritarian & Permissive \\
\hline Academic & & & \\
Performance & $.291^{* * *}$ & $-.126^{*}$ & $-.253^{* *}$ \\
Motivation & $.187^{*}$ & -.084 & $-.327^{* * *}$ \\
Communication & $.325^{* * *}$ & $-.288^{* * *}$ & -.080 \\
Learning & $.236^{* *}$ & -.044 & $-.356^{* * *}$ \\
Creativity & $.314^{* * *}$ & -.134 & -.081 \\
Positive Attitude & .102 & -.112 & -.101 \\
Study Skill & .147 & .084 & $-.179^{*}$ \\
Marks & $.163^{*}$ & -.148 & -.063 \\
\hline
\end{tabular}

Table 7 shows that the authoritative style has significant positive correlation with academic performance and its indicators except positive attitude and study skills. The Authoritarian style have negative correlation with academic performance but relationship is significant only for communication skills. The Permissive style has negative correlation with academic performance but relationship is significant only with motivation, learning skills and study skills. There is a weak correlation between academic performance and authoritarian. The range of correlation co-efficient varies from .044 to .356.

\section{Discussion}

A positive correlation was found between authoritative parenting style of both parents and children's academic performance. The hypothesis that authoritative maternal parenting style has positive correlation with academic performance was supported by the results of the study. The results also supported the hypothesis that authoritative paternal parenting style has positive correlation with academic performance. Results are consistent with previous findings in which authoritative parenting was found to be positively related to high levels of academic performance (Abar, Carter, \& Winsler, 2009; Watabe, 2011 cited in Monika \& Asudani, 
2013). The characteristics of authoritative parenting style i.e., warmth, supervision \& psychological autonomy granting, have a positive association with the grades achieved at school level (Deslandes, 1996 cited in Nyarko, 2011).Research has shown a positive correlation between authoritative parenting style and academic achievement (Slaten, 2006; Roche et al., 2007; Simons \& Conger, 2007; Pong, Johnston \& Chen, 2010). The research suggests many reasons for positive outcome of this parenting as the authoritative parents present themselves as role models and demonstrate same behaviors as they want from their children. Children may learn to internalize these behaviors. Fixed rules and discipline may educate the children about their responsibilities. Authoritative parents display emotional understanding and exhibit adequate control, as a result children might learn to understand others' emotions and also learn to manage their own sentiments. Children reared by these parents learn to act independently, which enables them to accomplish things on their own, and also help them to foster strong self-esteem and self-confidence. These qualities might enable children to excel in academic setting as well as in practical life. In order to promote positive parenting, it is recommended to organize events for interaction of parents in schools. In this way, they will share their parenting styles and disciplinary techniques with each other, it will further create an awareness of positive parenting styles.

A negative correlation was found between authoritarian style of both parents and children's academic performance. The hypothesis that authoritarian maternal parenting has negative correlation with children's academic performance is supported by the study. The results of the study also supported the $5^{\text {th }}$ hypothesis that authoritarian paternal parenting has negative correlation with children's academic performance. The results are consistent with previous studies in which authoritarian parenting was found to be negatively associated with educational outcome (Kordi \& Baharudin, 2010; Alsheikh et al., 2010; Attaway \& Bry, 2004). Research suggests that authoritarian parents demand complete obedience. Children raised under these parents are exceptionally good at following rule but they may lack self-discipline. They are not encouraged to explore and act independently; as a result they become unable to set their own limits and personal standards. So with all these deficiencies in these children, it's hard to become a competent and thriving student. It is recommended for schools, communities, and media groups to play their role in raising parental awareness about the benefits of engaging in their children's education, and to provide them with the opportunities and skills to do so. It is also recommended for principals of educational institutions to 
arrange different parent-teacher meetings and workshops with special focus on awareness of parenting roles.

A negative correlation was found between permissive parenting style of both parents and children's academic performance. But this parenting style of both parents was found to be non-significantly correlated with marks of children. The hypothesis that the permissive maternal parenting style is negatively related to children's academic performance is supported by the study results. The study also supports the hypothesis that the permissive paternal parenting style is negatively related to children's academic performance. The results are consistent with previous findings as Watabe (cited in Monika \& Asudani, 2013) found that permissive parenting style has negative correlation with academic achievement. Research studies found that permissive parenting and academic achievement display significant correlation (Lee eta l., 2006; Roche et al., 2007). Literature suggests that Permissive parenting exhibit less demands and expectations, so the children raised by these parents lack self-discipline. They show reluctance to follow rules in school because they experience lack of boundaries in the home. These children may show less academic motivation as compared to their peers. These parents rarely demand mature behavior, so children may lack social skills. These deficiencies of child may be a hurdle in getting academic excellence. For reconstructing parents' roles as a parent, they should be helped by community, educational institutions and teachers. The role construction effects parents' decisions about how and whether to become engaged in their children's education.

\section{Conclusion}

The results of the study revealed a positive relationship between authoritative parenting style and academic performance. While the authoritarian and permissive parenting style were found to be negatively related to academic performance.

Overall, this study is a contribution to the particular research area addressing importance of parenting and its relation to students in Pakistan's context. It is hoped that the findings of this study would be significantly beneficial for the participants of the study; both the students and parents, in understanding the effects of parenting styles on the academic performance of their children. Furthermore, this study would also be useful for teachers, schools, policy makers and curriculum developers, to help them in order to create the awareness of parenting styles. 
Parental Authority Questionnaire (Buri, 1991)

Appendix 1

(Modified scale for Parents)

\section{PART-1: MOTHER}

1. I feel that in a well-run home the children should have their way in the family as often as the parents do.

2. Even if my child doesn't agree with me, I feel that it is for his/her own good if she/he is forced to conform to what I think is right.

3. Whenever I tell my children to do something, I expect them to do it immediately without any questions.

4. Once family policy is established, I discuss the reasoning behind the policy with my child.

5. I always encourage verbal give-and-take whenever my children feel that family rules and restrictions are unreasonable.

6. I feel that what children need is to be free to make up their own minds and to do what they want to do, even if this does not agree with what their parents might want.

7. I do not allow them (children) to question any decision I have made.

8. I direct the activities and decisions of the children of my family through reasoning and discipline.

9. I feel that more force should be used by parents in order to get their children to behave the way, they are supposed to.

10. I do not feel that children need to obey rules and regulations of behavior simply because someone in authority had established them.

11. My children know what I expect them in my family, but they (children) also feel free to discuss those expectations with me when they feel that these are unreasonable.

12. I feel that wise parents should teach their children early just who the boss is in the family.

13. I seldom give them expectations and guidelines for their behavior.

14. I do what children want when making family decisions.

15. I consistently give them (children) direction and guidance in rational and objective ways. 
16. I get very upset if my children try to disagree with me.

17. I feel that most problems in society would be solved if parents would not restrict their children's activities, decisions, and desires as they are growing up.

18. I let my child know what behavior is expected of him/her, and if he/she does not meet these expectations, I punish him/her.

19. I allow my child to decide most things for her/himself without a lot of direction from me.

20. I take my children's opinions into consideration when making family decisions, but I will not decide something simply because he/she wants it.

21. I do not view myself responsible for directing and guiding his/her behavior.

22. I have clear standards of behavior, but I am willing to adjust those standards to my child's needs.

23. I give him/her direction for his/her behavior and activities and I expect him/her to follow my direction, but I am always willing to listen to his/her concerns to discuss that direction with him/her.

24. I allow my child to form his/her own point of view on family matters and I generally, allows him/her to decide for him/herself what he/she is going to do.

25. I feel that most problems in society would be solved if we could get parents to strictly and forcibly deal with their children when they don't do what they are supposed to as they are growing up.

26. I often tell my child exactly what I want him/her to do and how I expect him/her to do it.

27. I give my child clear direction for his/her behavior and activities, but I am also understanding when he/she disagree with me.

28. I do not direct the behavior, activities, and desires of them (children).

29. My child knows what I expect of him/her in the family and I insist that he/she should conform to those expectations simply out of respect for my authority.

30. If I make a decision in the family that hurts my child, I am willing to discuss that decision with him/her and to admit if I make a mistake. 


\section{Appendix 2}

\section{Academic Performance Questionnaire}

Indicators of academic performance:

\begin{tabular}{|l|l|}
\hline Motivation 1-6 (question) & Creativity 19-24 \\
\hline Communication skills 7-12 & Positive Attitude 25-32 \\
\hline Learning Skills 13-18 & Study Skills 33-38 \\
\hline
\end{tabular}

\begin{tabular}{|c|c|c|c|c|c|c|}
\hline $\begin{array}{l}\text { Sr. } \\
\#\end{array}$ & Questions & $\begin{array}{c}\text { Strongly } \\
\text { Agree }\end{array}$ & Agree & Uncertain & Disagree & $\begin{array}{l}\text { Strongly } \\
\text { Disagree }\end{array}$ \\
\hline 1 & $\begin{array}{l}\text { I participate more when class } \\
\text { work involves interesting tasks. }\end{array}$ & & & & & \\
\hline 2 & $\begin{array}{l}\text { I prefer course material that } \\
\text { really challenges me so I can } \\
\text { learn new things. }\end{array}$ & & & & & \\
\hline 3 & $\begin{array}{l}\text { The most important thing for } \\
\text { me right now is improving my } \\
\text { overall grade point average, so } \\
\text { my main concern in study is } \\
\text { getting a good grade. }\end{array}$ & & & & & \\
\hline 4 & $\begin{array}{l}\text { I want to do well in studies } \\
\text { because it is important to show } \\
\text { my ability to my family, friends, } \\
\text { or others. }\end{array}$ & & & & & \\
\hline 5 & $\begin{array}{l}\text { I do not find my studies very } \\
\text { interesting so I keep my work } \\
\text { to the minimum. }\end{array}$ & & & & & \\
\hline 6 & $\begin{array}{l}\text { I choose assignments that I } \\
\text { can learn from even if they } \\
\text { don't guarantee a good grade. }\end{array}$ & & & & & \\
\hline 7 & $\begin{array}{l}\text { I like to share ideas with my } \\
\text { friends. }\end{array}$ & & & & & \\
\hline 8 & $\begin{array}{l}\text { I feel confident in participating } \\
\text { class discussion. }\end{array}$ & & & & & \\
\hline 9 & $\begin{array}{l}\text { I feel frustrated because it is } \\
\text { difficult for me to communicate } \\
\text { with other students. }\end{array}$ & & & & & \\
\hline 10 & $\begin{array}{l}\text { I get upset because other } \\
\text { students and teachers cannot } \\
\text { understand me. }\end{array}$ & & & & & \\
\hline
\end{tabular}




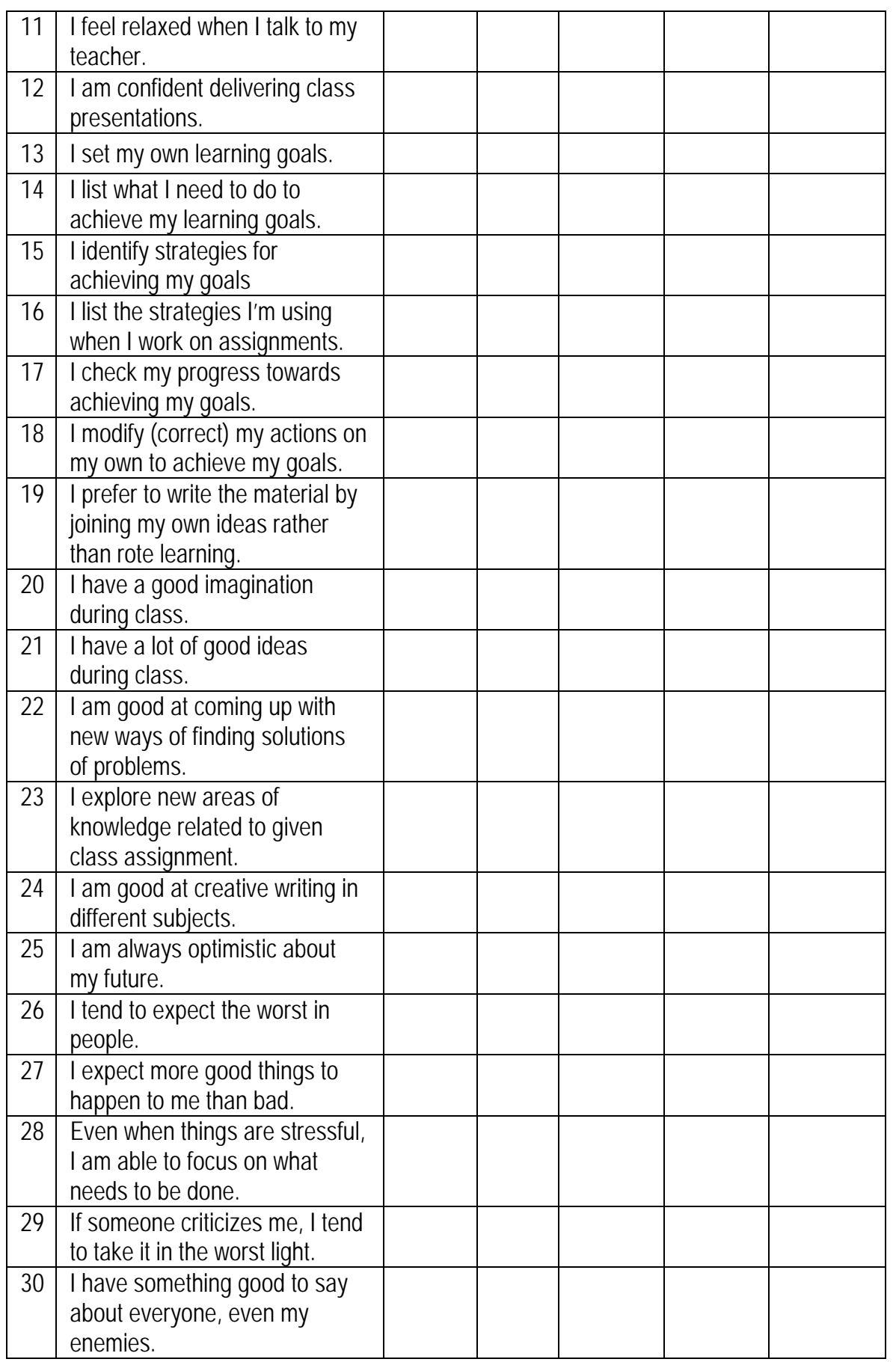


Samina \& Almas

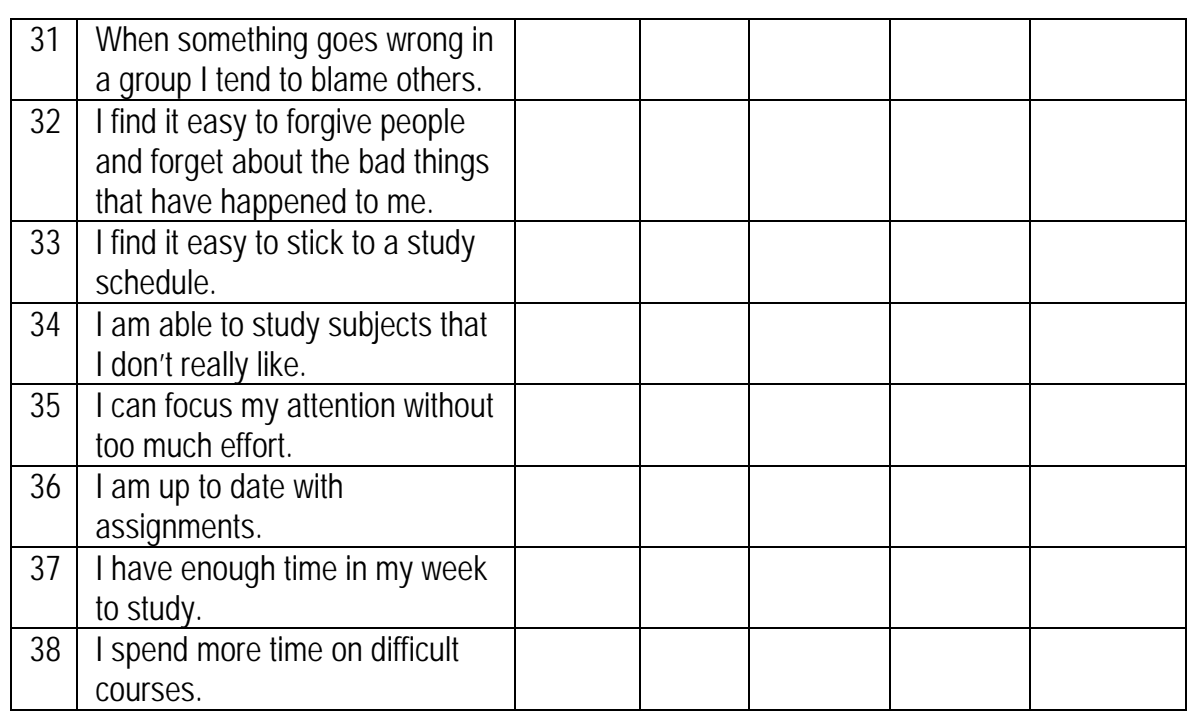




\section{REFERENCES}

Abar, B., Carter, K.L., \& Winsler, A. (2009). The effects of maternal parenting style and religious commitment on self-regulation, academic achievement, and risk behavior among African-American parochial college students. Journal of adolescence, 32(2): 259-273

Alsheikh, N., Parameswaran, G., \& Elhoweris, H. (2010). Parenting style, selfesteem and student performance in the United Arab Emirates. Current issues in education., 13(1). Retrieved from: http://cie.asu.edu/ojs/ index.php/cieatasu/article/viewFile/265/129

Attaway, N. M., \& Bry, H. B. (2004). Parenting style and black adolescents' academic achievement. Journal of Black Psychology, 2(30), 229-247. http://dx.doi.org/10.1177/0095798403260720

Baumrind, D. (1971). Current patterns of parental authority. Developmental Psychology Monographs. 4(1, Pt.2) 1-103.

Baumrind, D. (1991). Parenting styles and adolescent development. Journal of Early Adolescence 11(1) 56-95. doi: 10.1177/0272431691111004

Berg, B. (2011). The effects of parenting styles on a preschool aged child's social emotional development. The Graduate School, University of WinsconsinStout. Retrieved April 7, 2015, from: http://www2.uwstout.edu/ content/lib/thesis/2011/2011bergb.pdf.

Buri, J. (1991). Parental Authority Questionnaire. Journal of personality and Social Assessment. 57(1): 110-119.

Cramer, K. E. (2002). The influence of parenting styles on children's class room motivation. Retrieved April 7, 2015, from: http://etd.lsu.edu/docs/ available/etd-0712102-125121/unrestricted/Cramer_thesis.pdf.

Dornbusch, S. M., Ritter, P. L., Leiderman, P. H., Roberts, D.F., \& Fraleigh, M. J. (1987). The relation of parenting style to adolescent school performance. Child Development, 58, 1244-1257.

Hoghuighi, M. \& Long, N. (2004). A Handbook of Parenting. Theory and research for practices. London: Sage Publications Ltd.

Kaisa, A., Hakan, S., \& Jari-erik, N. (2000). Parenting styles and adolescents' achievement strategies. J. Adolesc., 23(2): 205-222.

Kordi, A. \& Baharudin, R. (2010). Parenting attitude and style and its effect on children's school achievements. International Journal of Psychological Studies, 2(2), 217-222.

Lazar, A., Guttmann, J., \& Abas, L. (2009).Parental authority in divorced families. Journal of Divorce \& Remarriage, 50(5), 356-368. 
Lee, S. M., Daniels, M. H.,\& Kissinger, D. B. (2006). Parental Influences on Adolescent Adjustment. Family Journal, 14(3), 253-259. http://dx.doi.org/10.1177/1066480706287654

Mckay, M. (2006). Parenting Practices in Emerging adulthood: Development of a new measure. Retrieved April 7, 2015, from: http://scholarsarchive. byu.edu/cgi/viewcontent.cgi?article $=1452$ \&context $=$ etd

Nyarko, K. (2011). The influence of authoritative parenting style on adolescents' academic achievement. American Journal of Social and Management Sciences, 2(3), 278-282.

Roche, K. M., Ensminger M. E., \& Cherlin A. J. (2007). Parenting style and adolescent outcomes among African and Latino families living in low income. Journal of Family Issue, 11(23), 882-909. Retrieved from: http://dx.doi.org/10.1177/0192513X07299617

Rossman B. B. R., \& Rea J. G. (2005). The relation of parenting styles and inconsistencies to adaptive functioning for children in conflictual and violent families. Journal of Family Violence, 20(5), 261-277. doi: 10.1007/s10896-005-6603-8

Simons, G. L., \& Conger, R. D. (2007). Linking father-mother differences in parenting to a typology of parenting style and adolescent outcomes. Journal of Family Issue, 28(2), 212-241. http://dx.doi.org/ 10.1177/0192513X06294593

Slaten, C. D. (2006). The effect of parenting style and family structure on academic achievement in rural setting. Doctoral dissertation, Truman State University. Retrieved from: http://proquest.umi.com

Pong, S., Johnston J., \& Chen V. (2010). Authoritarian parenting and Asian adolescent school performance: Insights from the US and Taiwan. International Journal of Behavior Development, 34(1), 62-72. Retrieved from: http://dx.doi.org/10.1177/0165025409345073

Monika, R. S., \& Asudani, V. H. (2013). Parenting Styles \& Their Impact on Educational Performance of Children at High School Level: Review of Literature. Indian Streams Research Journal, 3(7), Retrieved from: http://isrj.org/UploadedData/2809.pdf

Zupancic, M., Podlesek, A., \& Kavcic, T. (2004). Parental child care practices of Slovenian preschoolers mothers and fathers: The family environment questionnaire. Horizons of Psychology, 13(3), 7-26.

Received on: June $11^{\text {th }} 2015$

Revised on: October $10^{\text {th }} 2015$

Accepted on: November $06^{\text {th }} 2015$ 